\title{
RELATIONSHIP OF KNOWLEDGE AND SELF-REGULATION WITH NURSES' PREPAREDNESS FACING SMOKE DISASTER IN PONTIANAK CITY
}

\author{
Nurdin*, Nurdiana, Yati Sri Hayati \\ Nursing Master program, University of Brawijaya, Indonesia \\ *Corresponding Author's Email: nurdin_ns@yahoo.co.id
}

\begin{abstract}
Smoke haze disaster that occurred in 2015 due to forest and land fire caused suffering to about 503,874 people with acute respiratory infection (ARI) and caused death of 26 people and huge economic losses that reached 200 trillion and 43 million people were exposed to smoke haze. The research purposes in this study was to analyze the correlation of knowledge and self-regulation against the nurse' preparedness in community health center in facing smoke haze disaster in Pontianak. The method used was analytical survey with cross sectional approach with total respondents of 90 nurses in health center that was collected by simple random sampling. Nurses' preparedness was measured by using Emergency Preparedness Information Questionnaire. The test result of spearman ranks explained the correlation between knowledge $(p=0.036)$, but there was no correlation of self-regulation ( $p=0.074)$ with the nurses' preparedness in community health center in facing smoke haze disasters in Pontianak. Analysis of logistic regression explained that knowledge with calculated value of Exp $(B=3.378)$ was the most related variable against the nurses' preparedness in health center compared with selfregulation. Therefore from the study it was evident that knowledge of nurses about the disaster was substantial in aspect to management process of disaster in both preparedness phase and response phase.
\end{abstract}

\section{Keywords: Knowledge, Self-regulation, Preparedness, Smoke haze disaster}

\section{INTRODUCTION}

Large-scale disaster can have a major impact on individual, family and community, thus, it poses a threat to the quality of life (ICN and WHO 2009). Disaster impacts on humans and environment such as mass death, disability, poverty, hunger and destruction of infrastructure (Mizan, 2012).

The biggest challenge in managing disaster is to reduce disaster risk. According to data in 2015-2017, disaster had occurred for 1582, 2334 and 2164 times. It meant, there were five times more of disaster that struck Indonesia in a day, including forest fire disaster (BNPB, 2017). Forest and land fire in Indonesia occurred 634 times in every dry season from 2015 to 2017 (BNPB, 2017).

Smoke haze disasters that occurred in 2015 due to forest and land fire was the greatest disaster after 1997 due to El Nino phenomenon (Arfan, 2016). Smoke haze occurred between July to October of 2015, according to data of BNPB. There were 503,884 people with ARI (acute respiratory infection) scattered in various provinces such as South Sumatra, Riau, Jambi, South Kalimantan, Central Kalimantan and West Kalimantan, and caused deaths of about 26 people. Besides patients with acute respiratory infections, the impact of smoke haze due to forest and land fire caused huge economic losses that reached 200 trillion and 43 million people were exposed to smoke haze (Pusponegoro \& Sujudi, 2016; BNPB, 2017). Due to this severity of smoke haze impact, disaster management is required to reduce the impact of smoke haze disasters.

Disaster management is a collection of several strategies like administrative provisions and all activities that were practical and interrelated to the phases of disaster management. Phases of disaster management 
which consisted of planning and preparing. The main priority in disaster management was preparedness phase (ICN \& WHO 2009).

Nurses' preparedness in disaster management consisted of series of planning along with nurses' preparedness that carried out in preventing and reducing the effects of disasters to manage and create effective strategies to be prepared in case of emergency disaster management (ICN \& WHO 2009). There were two factors that affected the nurses' preparedness in managing disaster i.e. preparedness for knowledge and self-regulation (Baack, 2011; Sangkala \& Gerdtz, 2017). Nurses being health care workers, who are called first taking the role as first responder care providers, care coordinators, information providers or educators, mental health counselors, and became a triage officer during disaster (Pang et al., 2009).

Nurses were required to provide emergency assistance based on a sense of humanity. But nurses believed that there are other people who were responsible and competent to do the assistance (Hasyim \& Prasetyo, 2012). ICN and WHO in 2009 declared nurses had shown their participation in various disaster situations, with basic knowledge, skills, and capabilities and strives to support and provide assistance on humanitarian grounds and positively contribute to disaster response (ICN \& WHO 2009). However, nurses find it difficult to overcone this complex challenge in identifying the preparedness and dealing with disaster response when disaster occurred (Veenema, 2006; Veenema et al., 2016).

One of the main issues of nurses' preparedness in phase of disaster management was the lack of knowledge about disaster management including knowledge about disaster preparedness, disaster response, rehabilitation and recovery after disaster (Chapman \& Arbon 2008). Other studies show that preparedness against disaster, disaster response and disaster evaluation were low among nurses still low (Oztekin et al., 2016).

\section{METHODOLOGY}

This study used analytical survey design with cross sectional approach with total respondents of 90 nurses from health center based on inclusion criteria. The sampling conducted was simple random sampling technique. This study was conducted in 23 health centers in working area of Pontianak. Analysis of bivariate and multivariate was conducted using spearman ranks test and logistic regression test. Measurement of nurses' preparedness was conducted using Emergency Preparedness Information Questionnaire(EPIQ).

\section{RESULT}

Table 1: Characteristics of respondents based on age

\begin{tabular}{|c|c|c|c|c|c|}
\hline Variable & $\mathbf{N}$ & Mean & Median & Min-Max & SD \\
\hline Age & 90 & 37.96 & 38 & $23-57$ & 9.341 \\
\hline
\end{tabular}

Table 1 shows that youngest respondent was 23 years old and the oldest was 57 years old with a mean value of 37.96 .

Table 2: Characteristics of respondents based on gender, education, knowledge, self-regulation, and the nurses' preparedness

\begin{tabular}{|l|l|l|l|l|}
\hline No & Variables & Category & $\mathbf{f}$ & $\mathbf{\%}$ \\
\hline 1 & Gender & Male & 12 & 13.3 \\
& & Female & 78 & 86.7 \\
\hline 2 & Education & D3 & 53 & 58.9 \\
& & SPK & 21 & 23.3 \\
& & S1+Nurses & 12 & 13.3 \\
& & D4 & 4 & 4.4 \\
\hline 3 & Knowledge & Well & 46 & 51.1 \\
& & Less & 44 & 48.9 \\
\hline 5 & Self-regulation & Well & 79 & 87.8 \\
& & Less & 11 & 12.2 \\
\hline 8 & Nurses & High & 51 & 56.7 \\
& preparedness & Low & 39 & 43.3 \\
\hline \multirow{2}{*}{ Total } & & 90 & 100 \\
\hline
\end{tabular}

Table 2 show that the most dominant gender of respondents was female being 78 individuals. The most dominant education of respondents was D3 with 53 people. The most dominant knowledge of respondents showed 46 individuals. The most dominant selfregulation of respondent was well with 79 people. The most dominant nurses' preparedness was high with 51 individuals.

Table 3: Correlation knowledge and nurses's preparedness in community health center in facing smoke haze disaster in Pontianak

\begin{tabular}{|l|l|}
\hline & Preparedness of nurses \\
\hline Knowledge & $r=0.221$ \\
& $p=0.036$ \\
$n=90$ \\
\hline
\end{tabular}


Table 3 explained that the result of statistical test analysis obtained by $p$ value 0.036 , where the value of $p<\alpha$. Thus, the researcher could conclude there was correlation between knowledge and nurses' preparedness in community health center in facing smoke haze disaster in Pontianak. The value of $r 0.221$, described a positive direction correlation with weak correlation strength.

Table 4: Correlation of self-regulation and nurses' preparedness in community health center in facing smoke haze disaster in Pontianak

\begin{tabular}{|l|l|}
\hline & Preparedness of nurses \\
\hline Self-regulationr & $r=0.189$ \\
& $p=0.074$ \\
$n=90$ \\
\hline
\end{tabular}

Table 4 explained that statistical test analysis result obtained $p$ value of 0.076 , where the value of $p>\alpha$. Thus, it could be concluded that there was no correlation between self-regulation and nurses' preparedness in community health center with disasters smoke haze in Pontianak. The r value was $r=-0.189$, described negative direction correlation with weak correlation strength.

Table 5: The analysis results of multiple logistic regression between knowledge and self-regulation with the nurses' preparedness in community health center in facing smoke haze disaster in Pontianak

\begin{tabular}{|c|c|c|c|c|}
\hline Variables & Coefficient & $P$ value & $\operatorname{Exp}(B)$ & $\begin{array}{c}\text { Hosmer \& } \\
\text { Lameshow Test }\end{array}$ \\
\hline $\begin{array}{l}\text { Step 1 } \\
\text { Knowledge }\end{array}$ & 1.217 & 0.09 & 3.378 & \multirow{3}{*}{0.946} \\
\hline Selfregulation & -1.891 & 0.026 & 0.151 & \\
\hline Constanta & 1.347 & 0.88 & 3.846 & \\
\hline
\end{tabular}

Table 5 reveals the logistic regression analysis that explained the calculated value of $\operatorname{Exp}(B)$ for variable of knowledge was 3.378, the value of $\operatorname{Exp}$ (B) for variables of self-regulation was 0.151 .

The final result of logistic regression test showed the calculated value of Exp (B) for variable knowledge as 3378 , the value of $\operatorname{Exp}(\mathrm{B})$ for variable of self-regulation was 0.151 . According to this analysis, the variable of knowledge become independent variable that had the most dominant correlation against the preparedness with the value of Exp (B) was 3.378, which meant a good knowledge had 3 times higher chance of having a high preparedness compared with low knowledge after being controlled by self-regulation.
The model equation for multiple logistic regression test results was:

$\mathrm{y}=$ constant $+\mathrm{a} 1 \mathrm{x} 1+\mathrm{a} 2 \mathrm{x} 2$

$y=1374-1891+1217$

$y=0.7$

The value of equation would be calculated based on an equation to make predictions of disaster preparedness on nurses of health center nurses as follows:

$$
\begin{aligned}
& \mathrm{p}=\frac{1}{1+e^{-y}}=\frac{1}{1+2.7^{-0.7}} \\
& \mathrm{p}=0714=71.4 \%
\end{aligned}
$$

Based on the results of equation, then the probability of disaster preparedness was $71.4 \%$ with factors of knowledge and self-regulation that explained that there were $28.6 \%$ of other factors that was related to disaster preparedness. Furthermore, an assessment was conducted of quality model equation using values of discrimination and calibration. Discrimination value derived from the value of area under curve (AUC), with the AUC value of 0.675 (67.5\%). Calibration value obtained from Hosmer and lameshow test was a with the value of 0.946 .

\section{Table 6: Area Under Curve}

\begin{tabular}{|c|l|l|l|l|}
\hline Area & Error std. & Asymptotic sig b & \multicolumn{2}{|c|}{$\begin{array}{c}\text { Asymptotic } 95 \% \\
\text { confidence interval }\end{array}$} \\
\cline { 3 - 5 } & & & $\begin{array}{c}\text { Lower } \\
\text { bound }\end{array}$ & $\begin{array}{c}\text { Upper } \\
\text { bound }\end{array}$ \\
\hline 0.675 & 0.057 & 0.005 & 0.583 & 0.787 \\
\hline
\end{tabular}

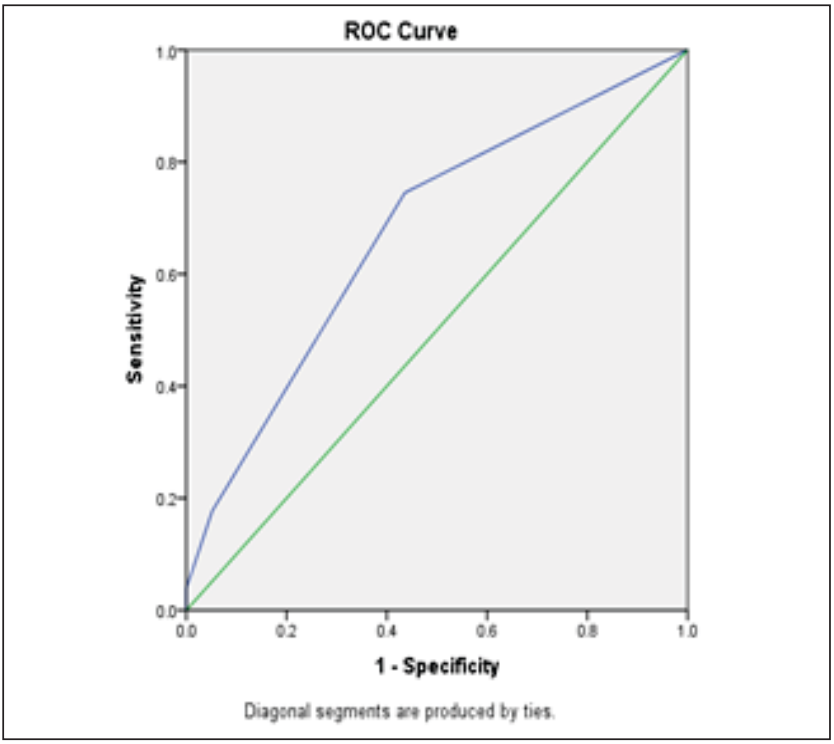

Figure 1: Roc curve as follows 


\section{DISCUSSION}

\section{Correlation between knowledge and nurses' preparedness in community health center in facing smoke haze disaster in Pontianak}

The study result conducted by researcher showed that there was correlation between the knowledge and nurses' preparedness in community health center in facing smoke haze disaster in Pontianak with $p$ value of $p=0.036$.

The study result was consistent with the result of Melnikov et al., (2014) which stated that there was significant correlation between nurses' knowledge and phase of preparedness when managing disaster. Several studies also described that nurses' knowledge in managing disaster is a substantial part in the phase of disaster management that not only had benefits for nurses, but also provided overall benefits for healthcare organizations in disaster-prone areas (Baack, 2011). Knowledge possessed by nurses to provide education and information to public about the importance of preparedness and response to disaster situation is very crucial (Groves, 2013).

Knowledge is one of the substantial part that must exist when establishing the intellectual aspects and human behavior related with what would be understood by human (Notoatmodjo, 2012). Knowledge possessed by individual about disaster maybe good or inadequate was based on several factors such as education, age and previous experience (Arsenijevic et al., 2017).

The results of study explained most of education level of nurses was D3 degree with percentage of $58.9 \%$, SPK degree with percentage of $23.3 \%$, while the education level of Nurses degree only reached a percentage of $13.3 \%$. According to Baker (2013) education could contribute to knowledge level acquired to influence the attitudes and behavior of people to participate in the disaster. This result was also in line with the study by Chen et al., (2017), that showed that education could facilitate nurses to improve knowledge about disaster, prompting the creation of disaster preparedness behaviors.

The study result stated that the youngest of the respondents was 23 years old and the oldest was 57 years old with a mean of 37.96. With the increase in age of each individual the mental development gets better. But after reaching a certain age, the cognition of individual starts decreasing affecting the ability of individuals to receive and manage information (Nugroho, 2010). According to Raes et al., (2015) the age of a person could give a good contribution to the process of mental development of each individual.

\section{Correlation between self-regulation and nurses' preparedness in community health center in facing smoke haze disaster in Pontianak}

The study result conducted by researcher showed that there was no correlation of self-regulation with nurses' preparedness in community health center in facing smoke haze disasters in Pontianak, with $p$ value of 0.074

The results of this study was not consistent with the study results conducted by Baack (2011) which described the correlation of self-regulation with nurses' preparedness in managing disaster. In this study, nurses working in health center showed a low percentage of $43.3 \%$, based on their self-regulation that was directly proportional to nurses' preparedness in managing disaster. Self-regulation required that nurse was responsible for carrying out the work in accordance with the role and functions in nursing practice. The behavior of self-regulation reflected the willingness of nurses to engage in disaster risk. Moreover, the interest of nurses' devotion in helping others that aimed to demonstrate the dedication and commitment along with motivation of nurses in disaster preparedness.

The concept of self-regulation was the ability to adapt positively to the environment with the ability in controlling the process and psychological behavior (Ghufron \& Risnawati, 2014). The factors that affected self-regulation are the level of knowledge/cognitive capacity of individual, behavior of individual and the environment (social and experience) (Ghufron \& Risnawati, 2014).

According to this study result explained that there were $48.9 \%$ of nurses who had less knowledge and the most of nurses' education level was D3 degree with percentage of $58.9 \%$. SPK degree with percentage of $23.3 \%$, while the education level of Nurses degree only reached a percentage of $13.3 \%$. If the knowledge and education of nurses was less, the nurse could experience difficult conditions in making appropriate decisions and will not be prepared to take action during disaster. Then the nurses' preparedness level will be low. Thus 
this will affect nurses' self-regulation. This was consistent with statement by Baker (2013) that stated education could contribute to knowledge level acquired, thus, influencing the attitudes and behavior of people to participate in disaster.

Human behavior considers all the activities carried out by human beings, seen directly and indirectly by another individual (Notoatmodjo, 2012). Human behavior could be influenced by the attitude in decisionmaking process based on specific reason (Azwar, 2013). Magnaye et al., (2011) stated that the attitude of nurses towards disaster preparedness was directly proportional to the degree of nurses' preparedness in managing disaster. The attitude of nurses towards disaster preparedness consists of two aspects: an attitude of rejection and acceptance. Both these attitudes would determine the awareness and willingness of nurses to participate in making preparations and disaster planning efforts. A good attitude or acceptance, not only increased the nurse's preparedness and affected their willingness to face disaster, but also would encourage nurses to increased their knowledge continuously about disaster preparedness (Mondargue \& Lircones, 2015).

Self-regulation referred to intrinsic motivation generated to take actions that might push someone toward a particular goal (Baack, 2011). Nurses' motivation related to self-regulation was influenced by previous experience. The nurses experience is one source of knowledge and also a method to get the validity of the knowledge acquired (Notoatmodjo, 2012). The study result of Ali (2015) explained that experience of nurses involved in delivery of health services during disaster situation yielded good preparedness compared with nurses who were never been involved in such disaster situations.

\section{CONCLUSION}

Based on the analysis results of multiple logistic regression test showed that variable of knowledge become independent variable with most dominant correlation with preparedness with value of Exp (B) was 3.378. This meant a good knowledge had about three times higher chance of having a high preparedness compared with low knowledge after being controlled by self-regulation. From this study it is evident that the nurse's knowledge about disasters is a important aspect in disaster management process in both preparedness and response phases of disaster, especially during smoke haze.

\section{ACKNOWLEDGEMENT}

The author would like to thank to all of the nurses who had been willing to become respondents of this study and all of Head of Community Health Center in Pontianak, Provincial Health Office of West Kalimantan, Health Office of Pontianak, and also Regional Disaster Management Agency of Pontianak which had contributed to the process of this study.

\section{REFERENCES}

Ali, N.M. \& Abu, I. (2015). Health-care providers' perception of knowledge, skills and preparedness for disaster management in primary health-care centers in jordan. Eastern Mediterranean Health Journal (EMHJ), 21(10), pp 713-721.

Arfan, A. (2016). Managing the Impact of Smoke Haze Disaster: Response of Civil Society Groups Towards Jambi Provincial Government Performance. Jurnal Bina Praja: Journal of Home Affairs Governance, 8(1), pp 59-68.

Arsenijevic, O., Trivan, D., Podbregar, I. \& Sprajc, P. (2017). Strategic aspect of knowledge management. Organizacija, 50(2), pp 163-177.

Azwar, S. (2013). Sikap Manusia Teori dan Pengukurannya edisi 2. Yogyakarta: Pustaka Pelajar.

Baack, S.T. (2011). Analysis of Texas Nurses' Preparedness and Perceived Competence in Managing Disasters. University of Texas, Tyler.

Baker, L.R. \& Cormier, L.A. (2013). Disaster preparedness and families of children with special needs: A geographic comparison. Journal of Community Health, 38(1), pp 106-112. 
BNPB (2017). Badan Nasional Penanggulangan Bencana: Data dan Informasi Bencana Indonesia [Online]. Retrieved from: http://bnpb.cloud/dibi/tabel1.

Chapman, K. \& Arbon, P. (2008). Are nurses ready ?: Disaster preparedness in the acute setting. Australasian Emergency Nursing Journal, 11(3), pp 135-144.

Chen, H., Chang, S.C., Feng, J.Y., Lin, S.J., Chen, L.C., Lee, C.L. \& Lai, F.C. (2017). Nurse participation in continuing education in nursing disaster in Taiwan. Journal of Emergency Nursing, 43(3), pp 197-202.

Ghufron, M.N. \& Risnawati, R. (2014). Teori-Teori Psikologi. Yogyakarta : Ar-ruzz Media.

Groves, S. 2013. Knowledge, Involvement and Emergency Preparedness. Master of Arts Thesis School of Mass Communications, College of Arts and Sciences University of South Florida. ProQuest LLC. UMI Number: 1543119.

Hasyim, M. \& Prasetyo, J. (2012). Etika Keperawatan. Yogyakarta: Bankit.

Internatioal Council of Nurses (ICN) and the World Health Organization (WHO) (2009). ICN Framework of Disaster Nursing Competencies. Retrieved from: http://www.wpro.who.int/hrh/documents/ icn_framework.pdf?ua $=1$

Magnaye, B., Munoz, S.L., Muñoz, M.A.F., Muñoz, R.G.V. \& Muro, J.H.M. (2011). The role preparedness and management of nurses during a disasters. E-International Scientific Research Journal, III(4), pp 269-294.

Melnikov, S., Itzhaki, M. \& Kagan, I. (2014). Israeli nurses' intention to report for work in an emergency or disaster. Journal of Nursing Scholarship, 46(2), pp 134-142.

Mizan, A.K. (2012). Peran Tenaga Kesehatan Dalam Penanggulangan Bencana. Journal Ilmia Kesehatan Media Husada, 01(01), pp 85-92.

Notoatmodjo, S. Oekidjo. (2012). Promosi kesehatan dan perilaku kesehatan. Jakarta: Rineka Cipta.

Nugroho, W. (2008). Keperawatan gerontik dan geriatrik. Edisi ketiga. Jakarta. EGC.

Oztekin, S.D., Larson, E.E., Akahoshi, M. \& Oztekin, I. (2016). Japanese nurses' perception of Reviews their preparedness for disasters: Quantitative survey research on one prefecture in Japan. Japan Journal of Nursing Science, 13(3), pp 391-401.

Pang, S.M.C., Chan, S.S.S. \& Cheng, Y. (2009). Pilot training program for developing disaster nursing competencies among undergraduate students in China. Nursing and Health Sciences, 11(4), pp 367-373.

Pusponegoro, A. \& Sujudi, A. (20160. Kegawatdaruratan dan Bencana Solusi dan Petunjuk Teknis Penanggulangan Medik dan Kesehatan, PT. Rayyana Komunikasindo.

Raes, E., Boon, A., Kyndt, E. \& Dochy, F. (2015). Measuring team learning through observing verbal Behaviors team interaction. Journal of Workplace Learning, 27(7), pp 476-500.

Sangkala, M.S. \& Gerdtz, M.F. (2017). Disaster preparedness and learning needs among community health nurse coordinators in South Sulawesi, Indonesia. Australasian Emergency Care, 21(1), pp 23-30.

Veenema, T.G. (2006). Expanding educational opportunitiesin disaster response and emergency preparedness for nurses. Nursing Education Perspectives, 27(2), 93-99.

Veenema, T.G., Griffin, A., Gable, A.R, Macintyre, L., Simons, R.N., Couig, M.P., Walsh, J.J., J.R., Lavin, R.P., Dobalian, A. \& Larson, E. (2016). Nurses as Leaders in Disaster Preparedness and Response - A Call to Action. Journal of Nursing Scholarship, 48(2), pp 187-200. 